\title{
First record of Panulirus regius (Decapoda: Palinuridae) in the Italian seas, with remarks on the earlier Mediterranean records
}

\author{
CARLO FROGLIA ${ }^{1}$, ROBERTO SILVESTRI ${ }^{2}$ AND FABRIZIO SERENA ${ }^{2}$ \\ ${ }^{1}$ clo CNR-Istituto di Scienze del Mare, U.O.S. Ancona, 60015 Ancona, Italy, ${ }^{2}$ Agenzia Regionale per la Protezione Ambientale della \\ Toscana, 57125 Livorno, Italy
}

The recent collection of four specimens of the royal spiny lobster Panulirus regius in the eastern part of the Ligurian Sea (Italy) is reported. Earlier records of this eastern Atlantic species along the coasts of the western Mediterranean Sea are revised and the possible ways of introduction are discussed.

Keywords: Decapoda, Palinuridae, Panulirus regius, range extension, Mediterranean Sea

Submitted 17 April 2011; accepted 25 September 2011

\section{INTRDDUCTIDN}

The increasing frequency of capture of thermophilic AtlantoMediterranean species, previously unknown in the Ligurian Sea has been related to global warming (Bianchi, 2007). This phenomenon is sometimes called 'meridionalization' of the northern sectors of the Mediterranean Sea (Riera et al., 1995; Cattaneo Vietti et al., 2010). Unintentional introduction of alien species, a consequence of the increase of maritime traffic, was also noticed and, among decapods, we can note the capture of single specimens of two alien portunid crabs: Callinectes sapidus Rathbun, 1906 (Bisconti \& Silvi, 2005) and Portunus pelagicus Linnaeus, 1758 (Crocetta, 2006) in the proximity of Livorno harbour.

Herein we report the capture of several specimens of the royal spiny lobster, Panulirus regius de Brito Capello, 1864, in the coastal waters north of Livorno. The species was previously unknown in the Italian seas (Froglia, 2010).

\section{MATERIALS AND METHDDS}

In September 2010 an artisanal fisher, working in the northern part of the Livorno maritime district (Ligurian Sea) with trammel nets (mesh $70 \mathrm{~mm}$ stretched) set at 5-10 m depth, targeting cuttlefish, reported to one of us (R.S.) the capture of a spiny lobster unknown to him. Due to the long antennular flagella, characteristic of the genus Panulirus, he called it 'lobster with six antennae'. The artisanal fishers in the Livorno harbour were alerted in the hope of obtaining more material. In the next four months we received three additional specimens from the same area (see list of material examined), and we are aware of the capture in November 2010 of at least three more specimens of similar size, one caught by a coastal trawler

Corresponding author:

C. Froglia

Email: c.froglia@alice.it fishing at $20 \mathrm{~m}$ depth. The examined specimens are deposited in the reference collection of the Agenzia Regionale per la Protezione Ambientale della Toscana, Livorno (L) and in the Museo Civico di Storia Naturale, Verona (V).

SYSTEMATICS

Order DECAPODA Latreille, 1802

Infraorder ACHELATA Scholts and Richter, 1995 Family PALINURIDAE Latreille, 1802

Genus Panulirus White, 1847

Species Panulirus regius de Brito Capello, 1864

(Figures 1, 2)

Synonyms: Palinurus Rissonii Desmarest 1825;

Palinurus fasciatus-Risso, 1816 [nec P. fasciatus Fabricius, 1798].

\section{MATERIAL EXAMINED}

Male: carapace length $74 \mathrm{~mm}$, total length $19.5 \mathrm{~cm}$, weight 280 g. September 2010, off Tirrenia (Tuscany), half mile offshore, depth $8 \mathrm{~m}$, sandy bottom; trammel-net for cuttlefish, leg. U. Di Meglio. (L).

Male: carapace length $59 \mathrm{~mm}$, total length $17 \mathrm{~cm}$ weight 189 g. 29 October 2010, off Tirrenia, depth $10 \mathrm{~m}$, sandy bottom; trammel-net for cuttlefish, leg. I. Agasi. (L).

Male: carapace length $60 \mathrm{~mm}$, total length $17 \mathrm{~cm}$ weight 184 g. 28 November 2010, off Tirrenia, depth $5 \mathrm{~m}$, sandy bottom; monofilament trammel-net, leg. G. Casabona (specimen damaged in the net by an Octopus that detached one antenna and 3 legs) (L).

Female: carapace length $53 \mathrm{~mm}$, total length $15 \mathrm{~cm}$, weight 125 g, 2 January 2011, off Tirrenia, depth 5 m, sandy bottom; trammel-net for cuttlefish, leg. G. Casabona (antennae broken) (V).

\section{DISTINCTIVE CHARACTERS}

The long antennular flagella and the colour pattern-olive green with a narrow transversal whitish band on abdominal somites-makes $P$. regius immediately recognizable from the 


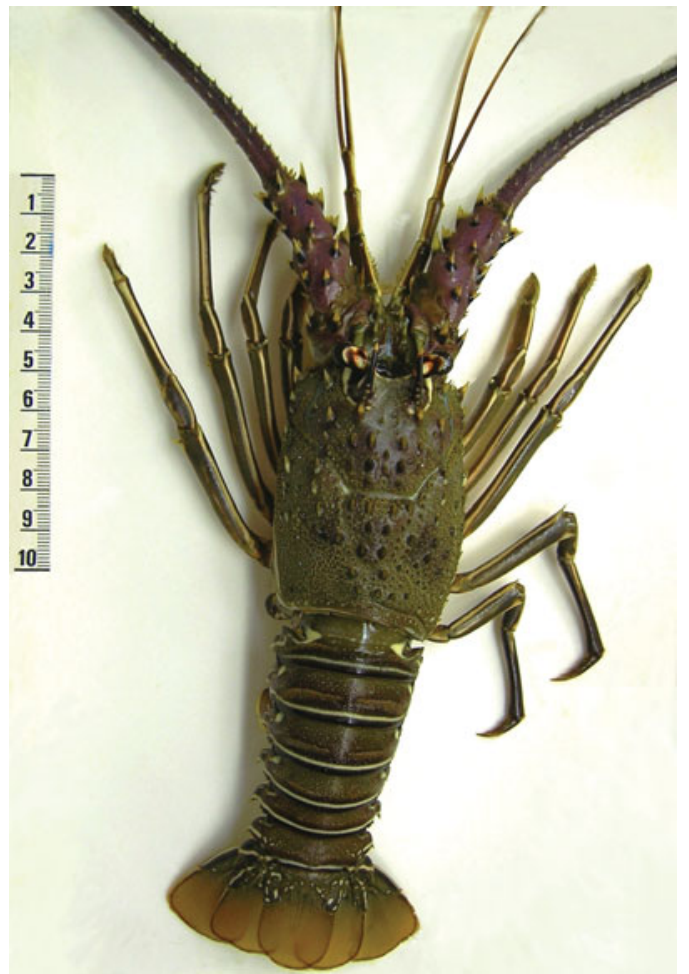

Fig. 1. Panulirus regius, male, Ligurian Sea, off Tirrenia (Livorno), 29 October 2010. Scale bar $=10 \mathrm{~cm}$.

other Mediterranean spiny lobsters (Palinurus elephas (Fabricius, 1785) and Palinurus mauritanicus Gruvel, 1911 that are reddish.

The presence of a non-crenulate, medially interrupted transverse groove on abdominal somites differentiates $P$. regius from the other Indo-Pacific species of Panulirus that have a somehow similar colour pattern. Other distinctive characters are the antennular plate with 4 large spines and the third maxilliped devoid of exopod.

\section{DISTRIBUTION}

This coastal species, rarely found at depths greater than $40 \mathrm{~m}$, is present along the east Atlantic coast from southern Morocco to Angola, including the Cabo Verde Archipelago (Holthuis, 1991). According to González (1995) the species is absent from the Canary Islands. It has also been recorded along the north-western Mediterranean coast (Holthuis, 1991: see Discussion).

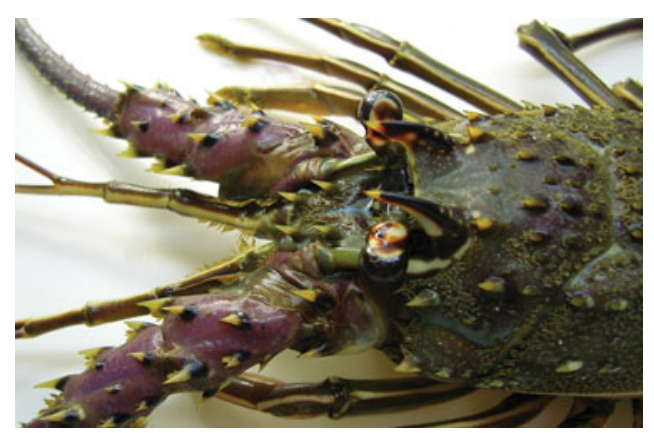

Fig. 2. Panulirus regius; detail of frontal region.

\section{DISCUSSIDN}

Panulirus regius is not considered as an alien species in the Mediterranean Sea (Holthuis, 1987; Galil et al., 2002). The species is known from the Mediterranean Sea since the 19th Century. Risso (1816) was the first author to report it from Nice (France) as Palinurus fasciatus (nec Palinurus fasciatus Fabricius, $1798=$ Panulirus polyphagus (Herbst, 1793)). Desmarest (1825) recognized Risso's misidentification and described it as a new species, named after Risso: Palinurus Rissonii. But later Risso regarded it as a simple variety of $P$. vulgaris (see Holthuis, 1977 , p. 487), followed in that by subsequent authors (Carus, 1885).

De Brito Capello (1864) described a new species of spiny lobster from the Cabo Verde Islands, naming it Panulirus regius. Holthuis (1946) pointed out the identity of Panulirus regius de Brito Capello, 1864 with Palinurus Rissonii Desmarest, 1825. Opinion 507 of the International Commission on Zoological Nomenclature in 1958, by suppressing the older name Palinurus Rissonii, made Panulirus regius the valid name for this species.

In the first years of the 2oth Century French and Spanish fishermen started to exploit the large stock of $P$. regius present in the coastal waters of Western Sahara and Mauritania. Vessels, equipped with running water systems in special holds to store the catch, were able to carry thousands of living spiny lobsters back to their home ports (Gruvel, 1911).

Darboux \& Stephan (1907) reported a new capture (two specimens) of the royal spiny lobster in the Mediterranean Sea-Gulf of Marseille-in 1907. They also registered assertions of old local fishers to have occasionally caught that species in the past, but suggested the two specimens had been introduced by fishing vessels, based in Marseille, that operated off West Africa in previous years. This hypothesis of escape of specimens from holding tanks was supported by Bouvier (1917) and again suggested by Zariquiey Alvarez (1968) to explain the occasional capture of $P$. regius along the Spanish Mediterranean coast mentioned by Zariquiey Cenarro (1935).

The above hypothesis may hold true for the records of the first half of the 2oth Century, when French and Iberian fishermen heavily exploited the spiny lobster stocks off West Africa. But the French fishery for the royal spiny lobster ended by the 1970s (Maigret, 1978; Pencalet-Kerivel, 2008).

Nowadays only few Portuguese vessels are allowed to exploit the royal spiny lobster resource off Mauritania, within a fishery agreement between the European Union and the Islamic Republic of Mauritania (European Community, 2008). They land live spiny lobsters at their home ports (Luis \& Calado, 2009). Live spiny lobsters, from the West African artisanal fishery, are currently exported to European countries by airfreight. But, according to the Italian Coast Guard deputed to do fishery control in Italy, no import of live or fresh fish was registered in the airports of Tuscany in the past year (F. Paolillo, personal communication).

Moreover all the specimens herein reported are below the minimum landing size $(21 \mathrm{~cm}$ from the tip of the rostrum to the end of the tail) fixed by the Protocol attached to the above mentioned EC Regulation and by Mauritanian national laws.

Therefore the hypothesis of the import of live animals and subsequent escape from a holding tank facility does not hold 
in the case of the present specimens, nor in the case of the specimens caught off Nice in the first years of the 19th Century, well before the start of the French fishery off West Africa, as already pointed out by Holthuis (1987).

Also an unintentional introduction of larvae with ballast waters, if it cannot be ruled out for the present records, does not apply to the material reported by Risso (1816) and Desmarest (1825), because at that time ships used only solid ballasts.

Lobsters of the genus Panulirus have a very long planktonic larval phase: over 300 days (Matsuda et al., 2006; Goldstein et al., 2008). Crosnier (1971) described 14 larval stages, inclusive of the 'puerulus' stage, for $P$. regius. Palinurid larvae, phyllosoma, can be transported over long distances by oceanic currents (Rudorff et al., 2009). It is worth remembering that the western Atlantic Panulirus argus (Latreille, 1804) has been repeatedly collected in the Cabo Verde Archipelago (Freitas \& Castro, 2006).

Therefore, even if the main current off Mauritania flows south-westward, we hypothesize that, under exceptional circumstances, coastal counter currents may drift larvae northward to the Strait of Gibraltar and these larvae may be trapped in the surface Atlantic water flowing into the Mediterranean Sea. The Atlantic water flows eastward in the Mediterranean Sea along the African continental slope, subject to intense mesoscale activity in the Algerian basin, then splits in several arms: one flows through the Strait of Sicily into the eastern Mediterranean whereas two others flow along the eastern Tyrrhenian coast and along the west coast of Corsica. These two arms enter the Ligurian Sea and continue to flow anti-clockwise (Millot \& Taupier-Letage, 2005; Cattaneo Vietti et al., 2010).

It is worthy of note that one of the Lagrangian drifters, equipped with ARGOS transmitter, launched in the Oran (Algeria) basin in October 1996, to investigate the flow of the Atlantic surface waters in the western Mediterranean Sea, was tracked by satellite until it reached the shores of Livorno in only 123 days (Font et al., 1998).

Thus a drift of larvae within the Atlantic water mass would explain the present captures of $P$. regius in the south-eastern part of the Ligurian Sea as well as the captures made in the north-western part (Nice) almost 200 years ago (Figure 3 ).

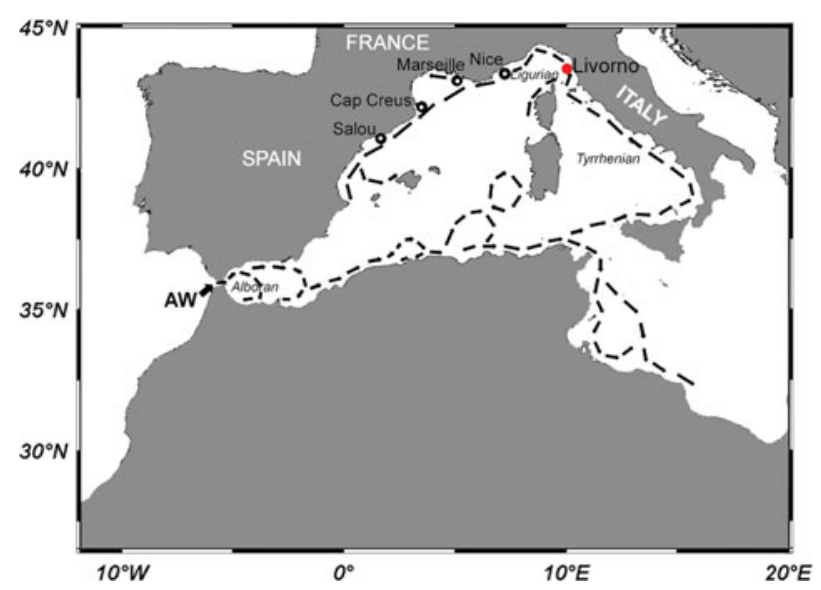

Fig. 3. Western Mediterranean: the main flow of surface Atlantic Water (AW) (adapted from Millot \& Taupier Letage, 2005) and the records of Panulirus regius: $\bullet$, present record, o, previous literature records.
The Mauritanian population of $P$. regius thrives in a coastal habitat strongly influenced by the upwelling of cold water masses, with annual temperatures ranging between $14^{\circ}$ and $21^{\circ} \mathrm{C}$ (Maigret, 1978) comparable to those observed along the northern coast of Tuscany. Thus the species could get established in the western Mediterranean. Why it has not yet succeeded is open to further speculation.

\section{ACKNOWLEDGEMENTS}

We thank the fishers, Isa (Taco) Agasi, Giusva Casabona and Umberto Di Meglio who made available the specimens of spiny lobsters herein discussed, their colleagues in the Livorno harbour who informed us of the other captures, and Commander Francesco Paolillo (Coast Guard, Livorno) for the information about sea-food import in Tuscany.

\section{REFERENCES}

Bianchi C.N. (2007) Biodiversity issues for the forthcoming tropical Mediterranean Sea. Hydrobiologia 580, 7-21.

Bisconti M. and Silvi E. (2005) Prima segnalazione di Callinectes sapidus Rathbun, 1896 (Crustacea, Decapoda, Brachyura) nella provincia di Livorno. Quaderni del Museo di Storia Naturale, Livorno 18, 1-6.

Bouvier E.L. (1917) Crustacés décapodes (Macroures marcheurs) provenant des campagnes des yachts Hirondelle et Princesse Alice (18851915). Résultats des campagnes scientifiques accomplies sur son yacht par Albert Ier Prince souverain de Monaco 50, 1-140, 11 pls.

Carus J.V. (1885) Prodromus Faunae Mediterraneae. Volume 1 Coelenterata, Echinodermata, Vermes, Arthropoda. Stuttgart: E. Schweizerbart'sche Verlagshandlung, $525 \mathrm{pp}$.

Cattaneo Vietti R., Albertelli G., Aliani S., Bava S., Bavestrello G., Benedetti Cecchi L., Bianchi C. N., Bozzo E., Capello M., Castellano M., Cerrano C., Chiantore M., Corradi N., Cocito S., Cutroneo L., Diviacco G., Fabiano M., Faimali M., Ferrari M., Gasparini G.P., Locritani M., Mangialajo L., Marin V., Moreno M., Morri C., Orsi Relini L., Pane L., Paoli C., Petrillo M., Povero P., Pronzato R., Relini G., Santangelo G., Tucci S., Tunesi L., Vacchi M., Vassallo P., Vezzulli L. and Wurtz M. (2010) The Ligurian Sea: present status, problems and perspectives. Chemistry and Ecology 26 (Supplement) 319-340.

Crocetta F. (2006) First record of Portunus pelagicus (Linnaeus, 1758) (Decapoda, Brachyura, Portunidae) in the northern Tyrrhenian Sea. Crustaceana 79, 1145-1148.

Crosnier A. (1971) Ponte et développement de la langouste verte Panulirus regius De Brito Capello dans le Sud du Golfe de Guinée. Cahiers ORSTOM-Océanographie 9, 339-361.

De Brito Capello F. (1864) Descripção de tres especies novas de Crustaceos d'Africa occidental e observações ácerca de Penoeus bocagei, Johnson, especie nova dos mares de Portugal. Memorias da Academia de Ciencias, Lisboa 3, 1-11, 1 pl.

Desmarest A.G. (1825) Considérations générales sur la classe des Crustacés, et description des espèces de ces animaux, qui vivent dans la mer, sur les côtes ou dans les eaux douces de la France. Paris: F.G. Levrault Libraire.

Darboux G. and Stephan P. (1907) Capture de palinuriens longicornes dans le Golfe de Marseille. La Feuille des jeunes Naturalistes 38, 16-17.

European Community (2008) Protocol setting out the fishing opportunities and financial contribution provided for in the Fisheries Partnership Agreement between the European Community and the 
Islamic Republic of Mauritania for the period 1 August 2008 to 31 July 2012. Official Journal of the European Union L203, 4-59.

Font J., Millot C., Salas J., Julià A. and Chic O. (1998) The drift of Modified Atlantic Water from the Alboran Sea to the eastern Mediterranean. Scientia Marina 62, 211-216.

Freitas R. and Castro M. (2006) Occurrence of Panulirus argus (Latreille, 1804) (Decapoda, Palinuridae) in the northwest islands of the Cape Verde Archipelago (Central-East Atlantic). Crustaceana 78, 11911201.

Froglia C. (2010) Crustacea, Malacostraca, Decapoda. Biologia Marina Mediterranea 17 (Supplement 1), 519-534.

Galil B.S., Froglia C. and Noël P. (2002) Crustaceans. CIESM Atlas of exotic species in the Mediterranean, Volume 2. Monaco: CIESM Publishers.

Goldstein J.S., Matsuda H., Takenouchi T. and Butler M.J. IV (2008) The complete development of larval Caribbean spiny lobster Panulirus argus (Latreille, 1804) in culture. Journal of Crustacean Biology 28, 306-327.

González J.A. (1995) Catalogo de los crustaceos decapodos de las Islas Canarias. Gambas, Langostas, Cangrejos. Santa Cruz de Tenerife: Publicaciones Turquesa S.L.

Gruvel A. (1911) Mission Gruvel sur la Côte occidentale d'Afrique (1909-1910). Résultats scientifiques et économiques. Annales de l'Institut Océanographique 3, 1-56, 6 pls.

Holthuis L.B. (1946) Biological results of the Snellius Expedition. XIV. The Decapoda Macrura of the Snellius Expedition. I. The Stenopodidae, Nephropsidae, Scyllaridae and Palinuridae. Temminckia 7, 1-177, pls $1-11$.

Holthuis L.B. (1977) The Mediterranean decapod and stomatopod Crustacea in A. Risso published works and manuscripts. Annales $d u$ Muséum d'Histoire Naturelle de Nice 5, 37-88.

Holthuis L.B. (1987) Homards, langoustines, langoustes et cigales. In Fischer W., Schneider M. and Bauchot M.-L. (eds) Fiches FAO d'identification des espèces pour les besoins de la pêche. Méditerranée et Mer Noire. Zone de pêche 37. Révision I. Volume I. Végétaux et invertébrés. Rome: FAO, pp. 293-319.

Holthuis L.B. (1991) Marine lobsters of the world. An annotated and illustrated catalogue of species of interest to fisheries known to date. FAO species catalogue. Volume 13. FAO Fisheries Synopsis 125, viii $+1-292$.
Luis O.J. and Calado R. (2009) Captive breeding of the Eastern Atlantic royal spiny lobster Panulirus regius in a recirculation system: a candidate for aquaculture in temperate zones. World Aquaculture 40, $22-$ $24,70-71$.

Maigret J. (1978) Contribution à l'étude des langoustes de la côte occidentale d'Afrique (Crustacea, Decapoda, Palinuridae). These de doctorat es Sciences naturelles. Universitè Aix-Marseille, Station marine d'Endoume, France.

Matsuda H., Takenouchi T. and Goldstein J.S. (2006) The complete larval development of the pronghorn spiny lobster Panulirus penicillatus (Decapoda: Palinuridae) in culture. Journal of Crustacean Biology $26,579-600$.

Millot C. and Taupier-Letage I. (2005) Circulation in the Mediterranean Sea. In Saliot A. (ed.) The Mediterranean Sea. Berlin and Heidelberg: Springer-Verlag, pp. 29-66. [The Handbook of Environmental Chemistry, no $5 / 5 \mathrm{~K}$.]

Pencalet-Kerivel F. (2008) La mort et le deuil de la pêche langoustière bretonne en Mauritanie. Annales de Bretagne et des Pays de l'Ouest $115,173-200$.

Riera F., Grau A.M., Pastor E. and Pou S. (1995) Faunistical and demographical observations in Balearic ichthyofauna. In La Méditerranée: variabilité climatique, environment et biodiversité. Montpellier: Actes Colloque Scientifique OKEANOS, pp. 213-220.

Risso A. (1816) Histoire naturelle des Crustacés des environs de Nice. Paris: Libraire Grecque-Latine-Allemande, 175 pp, 3 pls.

Rudorff C.A.G., Lorenzzetti J.A., Gherardi D.F.M. and Lins-Oliveira J.E. (2009) Modeling spiny lobster larval dispersion in the Tropical Atlantic. Fisheries Research 96, 206-215.

Zariquiey Alvarez R. (1968) Crustaceos Decapodos Ibericos. Investigacion Pesquera $32, \mathrm{xi}+1-510$.

and

Zariquiey Cenarro R. (1935) Los Palinuridae de las costas de España (Crust. Decap.). Boletín de la Sociedad Española de Historia Natural $35,311-330$.

\section{Correspondence should be addressed to:}

C. Froglia clo CNR-Istituto di Scienze del Mare U.O.S. Ancona, 60015 Ancona, Italy email: c.froglia@alice.it 